\title{
Borders in the Nō Play Birds of Sorrow
}

\author{
KoBAYASHI Kenji \\ Translated by Kristopher ReEves
}

$\mathrm{M}$ urai Shōsuke 村井章介, a noted scholar of Japanese history, has made a detailed investigation of the four cardinal geographical borders which seem to have played a prominent role in the medieval Japanese imagination. Two of this borders, in particular, are of special significance for the present discussion. According to Murai, medieval Japanese people considered the archipelago to be bounded on the north by a stretch of beach known as Sotogahama 外浜, the Outermost Shore. On the other hand, the southernmost extremity of the archipelago was delineated by an island known as Kikaigashima 鬼界島, Ogre's Isle. ${ }^{1}$ Murai cites a variety of literary and historical works in order to demonstrate just how firmly fixed within the geographical imagination these two borders had become. It is curious to note that most of the sources in which such records are to be found are works of fiction and not, as one might be inclined to expect, historical or archival documents. No doubt there is a reason for this.

In the world of performative genres, there is a $n \bar{o}$ 能 play by the name of $U t \bar{t}$ 善 知鳥 (Birds of Sorrow), which takes place in the aforementioned Sotogahama. ${ }^{2}$ This play, which belongs to the Kanze School 観世 repertoire, is mentioned in an entry from a Muromachi-period diary known as Chikamoto nikki 親元日記 (The Diary of Ninagawa Chikamoto 蜷川親元 [1433-1488], late $15^{\text {th }}$ century) dated the twenty-eight day of the second month in the sixth year of Kanshō 寞正 (1465). Here it is stated that this play was performed before the then acting shogun Ashikaga Yoshimasa 足利義政 (1436-1490, shōgun 1449-1473), when the latter paid a visit to Retired Emperor Go-Hanazono 後花園上皇 (1419-1470, r. 14281464) at his retirement palace. Utō opens, as so many other nō plays do, with an itinerant monk making his way to some famous place. In this case, the monk, having found his way to Mount Tate 立山 in Ecchū 越中 (modern-day Toyama), begins

\footnotetext{
${ }^{1}$ See Murai's article entitled “Sotogahama to Kikaigashima: chūsei kokka no kyōkai”" 外浜と鬼 界島一中世国家の境界, to be found in his monograph Nibon chüsei kyökai shiron 日本中世境界史 論. Tokyo: Iwanami Shoten, 2013.

${ }^{2}$ For an English translation of this play, see Donald Keene, ed. Anthology of Japanese Literature: From the Earliest Era to the Mid-Nineteenth Century (New York: Grove Press, 1955), pp. 271-285.
} 


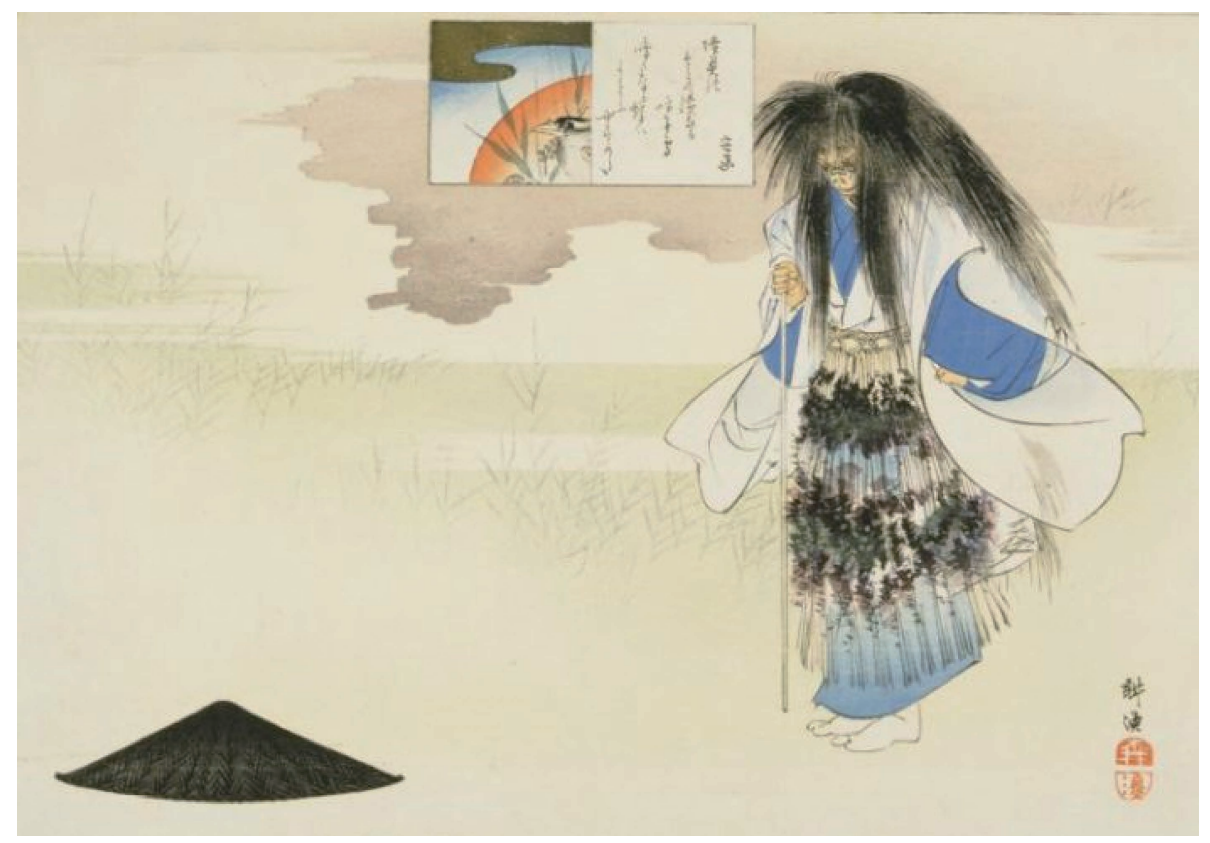

Figure 1. “Utō,” by the artist Tsukioka Kōgyo 月岡耕漁 (1869-1927), being part of a larger set of similar illustrations entitled Nögaku zue nibyaku gojūban 能楽図絵二百五 十番, currently belonging to Kokuritsu nōgakudō (item no. BK014-028).

to sing in detail regarding the visions of hell he has since witnessed throughout his torturous mountain hike. It is at this very moment that an elderly man suddenly appears before him. This fellow promptly informs the monk that he is no mortal, but the spirit of a hunter who passed away the previous year. The hunter implores the monk to travel to the northern provinces of Michinoku, all the way to Sotogahama, where his widowed wife and son still dwell, in order that the monk might hold a memorial service on behalf of his soul. Lest his wife should doubt the veracity of this monk, the hunter tears off one of his hempen sleeves, hands it to the monk, and vanishes. As per the deceased hunter's wishes, the monk travels northward to Sotogahama, where he pays a visit to the widowed wife and her child, informing them of how he came to know of their whereabouts. Showing her the hempen sleeve, she is astonished to see that it matches the one left behind by her husband. Certain now that the spirit who appeared to the monk was indeed that of her husband, the widow prays reverently before the straw raincoat and sedge hat once worn by her beloved. As if summoned by this gesture, her husband's spirit presently appears, looking bedraggled and weary (see Figure 1).

Though he longs desperately to embrace his child, he is not permitted to do so. As karmic retribution for having once snatched away the nestling of a hornbilled puffin $(u t \overrightarrow{0})$, thereby separating the bird forever from its mother, so, too, must the 
hunter forever be separated from his own child. He then proceeds to repent of his reckless actions, reenacting the manner in which he captured the nestling. It is, he laments, in virtue of this very act that he is condemned to suffer the torments of purgatory, and it is for this reason that he implores the monk's succor. Having thus revealed the truth of things, the spirit of the hunter once again vanishes.

Utō, masterpiece that it is, remains an anonymous work. As can be seen from the synopsis above, this piece belongs to that category of no plays referred to as obsession plays (shüshinmono 執心物), for, on top of his infernal torments, it is the hunter's restless desire to be reunited with his wife and child that keeps his soul wandering between this world and the next. The anonymous playwright has drawn upon a number of well-known sources, including, for example, a tale entitled "How the Girl Who Stumbled into Purgatory Whilst Hiking Through Mount Tate in Ecchū was Rescued by Jizō," found in the seventeenth fascicle of Konjaku monogatarishū 今昔物語集 (Tales Old and New, c. 1120). ${ }^{3}$ This tale succeeds in connecting a real geographical location, namely, Mount Tate, with a supernatural realm, that is, purgatory. It would appear the playwright has also drawn upon a Kamakura-period treatise on poetics known as Shinsen utamakura nayose 新撰歌 枕名寄 (New Anthology of Poems about Famous Places), which includes a legend about the utō bird.

In terms of plot-structure, Utó contains two acts, in accordance with the now classical style, first established by Zeami 世阿弥 (1363-1443), known as dream plays (mugen $n \bar{o}$ 夢幻能). There are generally only two dramatis personae: the primary protagonist (shite シテ)—the hunter, in the case of Uto- —and the auxiliary or secondary protagonist (waki ワキ), who, as in Utō, usually takes the form of an itinerant monk. That the secondary protagonist should take the form of a monk is in line with the otherworldly nature of the primary protagonist, who is necessarily a wandering spirit, for which reason these dream plays are often referred to as spirit plays (yüreino 幽霊能). These two-act dream plays commonly unfold in a rather straightforward manner: The play begins with the monk visiting a place which is eventually revealed to be the site of some significant event in the earthly life of the primary protagonist. The latter appears. Having appeared before the monk in the guise of, say, an old fisherman or farmer, the spirit of the deceased shares with his guest a curious tale which inevitably features someone whose life is bound up with the place. This tale, besides laying the groundwork upon with the play unfolds, also serves as a means of hinting to the monk that the primary protagonist is — rather was — the very fellow appearing in that tale. Once the tale has been told, the spirit vanishes into thin air, thus ending the first act. In the second act, the monk, moved by this tale, conducts certain

\footnotetext{
${ }^{3}$ For a complete translation of this work, see Dykstra, Yoshiko, trans., The Konjaku Tales. Intercultural Research Institute Monograph Series. Osaka: Intercultural Research Institute, Kansai University of Foreign Studies. 1986-1994.
} 
religious rites on behalf of its protagonist, be it reciting a sutra or intoning a simple prayer, whereupon the spirit again appears before him, only this time in the true likeness of his previous earthly form. The spirit reenacts his final hour, concluding this second visitation with a plea for salvation. Again, it is no accident that the secondary protagonist is a monk: only a monk is able to effectively pray for the condemned souls of deceased mortals.

While Utó follows this general structure, it exhibits one crucial difference. In most two-act dream plays, the spirit appears in both acts in this same location. The spirit of the deceased hunter, however, appears in two different places, first in Mount Tate, second in Sotogahama - two places separated by a very great distance. Though it may seem as though these two places are mutually unrelated, there is, in fact, something binding them together. As the tale of the girl who was rescued from purgatory at Mount Tate cited above reveals, this mountain was believed to contain an entranceway into the infernal underworld. In other words, Mount Tate functioned as a gateway between this world and the next. Similarly, Sotogahama, then imagined to mark the northernmost extremity of this mortal world, was, as its name- the Outermost Shore-implies, a boundary between this world and the world beyond. The monk who is able to wend his way between Mount Tate and Sotogahama is no normal monk. Utō opens with the monk saying words to the following effect: "As I have not yet engaged in meditation atop Mount Tate, it is thither I shall presently betake me. Thereafter I shall make the long journey on foot to the very farthest reaches of Michinoku." Meditation atop Mount Tate means much more than simply mountain climbing; it implies a series program of aesthetic training. The same applies to the lengthy trek to Sotogahama. The connection seen in Utō between Mount Tate and Sotogahama is based, no doubt, on an actual course of aesthetic training, engaged upon by itinerant monks seeking liberation through extreme physical and spiritual exertion.

As mentioned earlier, borders of this sort appear most commonly in works of fiction, being less frequent in historical documents. One reason for this is the simple fact that neither Mount Tate nor Sotogahama, to take these two as examples among many possible others, were official boundaries established by the central authorities. Quite the contrary. These borders existed primarily in the medieval imagination, finding repeated expression in works of fiction. As Utō so clearly indicates, however, these imagined borders were not mere fictions, but were inspired by the aesthetic practices, the actual hiking courses, of real-life itinerant monks. In this sense, these borders were very real indeed. 